\title{
Magyar kőrises égerlápok a Nyírségben (Fraxino pannonicae-Alnetum glutinosae Soó et Járai-Komlódi in Járai-Komlódi 1958)
}

\author{
Kevey Balázs ${ }^{1} \&$ Papp LÁszló ${ }^{2}$ \\ 1Pécsi Tudományegyetem, Ökológiai Tanszék, 7624 Pécs, Ifjúság u. 6. \\ e-mail: keveyb@gamma.ttk.pte.hu \\ 2Debreceni Egyetemi Botanikus kert, 4032 Debrecen, Egyetem tér 1. \\ e-mail: papp.laszlo@gf.unideb.hu
}

Kevey, B. \& PAPP, L.: Pannonian ash-alder swamps in the Nyirség.

Abstract: This study presents the results of phytosociological analyses of ash-alder swamps found in the Nyírség, NE Hungary. These swamps host a number of locally or regionally rare species, such as Urtica kioviensis, Thelypteris palustris, Hottonia palustris, Dryopteris carthusiana, Listera ovata, and Oenanthe banatica. Based on their phytosociological characteristics, these swamps are identified with Pannonian ashalder swamps (Fraxino pannonicae-Alnetum glutinosae Soó et Járai-Komlódi in Járai-Komlódi 1958) described in the Duna-Tisza köze sands.

Keywords: Syntaxonomy, alder swamp, cluster analysis, ordinatio

\section{Bevezetés}

Az Alnus glutinosa a Nyírségben többnyire ültetett formában található (PAPP in KeVEY \& PAPP 2000). Ebből következik, hogy a természetszerü erdőtársulásokban ritkán fordul elö. Kutatásaink során mindössze két erdőben találtuk meg a magyar kőrises égerlápot (Fraxino pannonicae-Alnetum), így a Nyírábránynál levő „Mogyorósi-erdő”-ben (1. ábra), valamint a Tiborszállás és Mérk közötti „Vadaskerti-erdő”-ben. E két erdőből összesen öt cönológiai felvételt sikerült készítenünk. Mivel e társulás a Nyírségben igen ritka, e kis felvételi anyag birtokában is fontosnak érezzük, hogy jellemezzük a magyar kőrises-égerlápokat.

\section{Anyag és módszer}

A cönológiai felvételeket a Zürich-Montpellier növénycönológiai iskola (BECKING 1957, BRAUN-BLANQUET 1964) hagyományos kvadrát-módszerével készítettük. A felvételek táblázatos összeállítását, valamint a karakterfajok csoportrészesedését és csoporttömegét az „NS” számítógépes programcsomag (KEVEY \& HiRMANN 2002) segítségével végeztük. A felvételkészítés és a hagyományos statisztikai számítások módsz- 
erét KeVEY (2008) korábban részletesen közölte. A Nyírség magyar kőrises-égerlápjait összehasonlítottuk a Duna-Tisza közéböl leírt Fraxino pannonicae-Alnetum-mal (Soó et JÁRAI-KOMLÓDI in JÁRAI-KOMLÓDI 1958). Az asszociációk összehasonlításánál a SYNTAX 2000 programcsomag (PoDANI 2001) segítségével bináris adatokon alapuló hierarchikus osztályozást, cluster-analízist (hasonlósági index: Baroni-Urbani-Buser; osztályozó módszer: teljes lánc) és szintén bináris alapú ordinációt (hasonlósági index: BaroniUrbani-Buser; ordinációs módszer: fökoordináta-analízis) készítettünk. A fajok esetében KIRÁLY (2009), a társulásoknál pedig az újabb hazai nómenklatúrát (BORHIDI \& KEVEY 1996, Kevey 2008, BorHIDI et al. 2012) követjük. A társulástani és a karakterfaj-statisztikai táblázatok felépítése az újabb eredményekkel (OBERDORFER 1992, MucINA et al. 1993, Kevey 2008, BoRHIDI et al. 2012) módosított Soó (1980) féle cönológiai rendszerre épül. A növények cönoszisztematikai besorolásánál is elsősorban Soó (1964, 1966, 1968, 1970, 1973, 1980) Synopsis-ára támaszkodtunk, de figyelembe vettük az újabb kutatási eredményeket is (vö. Borhidi 1993, 1995, Horváth F. et al. 1995, KeveY 2008).

Összehasonlítás céljából az elemzésekbe a Nyírségben készült magyar kőrises égerláp (Fraxino pannonicae-Alnetum) felvételek (Kevey et Papp ined.) mellett bevontuk a Nyírség kiszáradó kőrisláp (Veratro albi-Fraxinetum angustifoliae) felvételeit (KEVEY et al. 2019), továbbá a Duna-Tisza köze magyar kőrises égerláp (Fraxino pannonicae-Alnetum) felvételeit (JÁRAI-KomLóDI 1958), valamint a Duna-Tisza köze kiszáradó kőrisláp (Veratro albi-Fraxinetum angustifoliae) felvételeit (KEVEY 2020) is.

\section{Eredmények}

A Nyírség magyar kőrises-égerlápjaiból 2004 és 2007 között öt cönológiai felvételt (1-3. táblázat) készítettünk. Alább e felvételi anyag alapján adjuk meg a társulás jellemzését.

\section{Termöhelyi viszonyok}

A vizsgált magyar kőrises égerlápok a Nyírség homokvidékén, 123-147 m tengerszint feletti magasságban találhatók. Az alapkőzetet savanyú homokos öntésföld képezi, amelyen tőzeges láptalaj alakult ki. Az állományok mikroklímája hűvös, párás, talajuk a nedves vízgazdálkodási fokozatba sorolható. A magyar kőrises égerlápokat (Fraxino pannonicae-Alnetum glutinosae) a mélyebb termőhely felöl rekettye füzlápok (Calamagrostio-Salicetum cinereae), vagy fehér füzlápok (Carici elatae-Salicetum albae) szegélyezik. Az égerlápok (Fraxino pannonicae-Alnetum glutinosae) fokozatos elvíztelenedésével jönnek létre a valamivel magasabb szinten elhelyezkedő kiszáradó kőrislápok (Veratro albi-Fraxinetum angustifoliae) (1. ábra, KeVEY et al. 2019, KeVEY 2020).

\section{Fiziognómia}

A felső lombkoronaszint közepesen zárt, 60-70\% borítást mutat, magassága pedig az állomány korától függően - 20-25 méter. Az átlagos törzsátmérő ennek megfelelően 35 és $50 \mathrm{~cm}$ között változik. Állandó (K V) fái az Alnus glutinosa, a Fraxinus angustifolia ssp. danubialis és a Salix fragilis. Közülük az Alnus glutinosa és a Fraxinus angustifolia ssp. danubialis fordulhat elő nagyobb tömegben (A-D 3-4). Egyéb elegyfái a Populus alba és a Salix alba. Az alsó lombkoronaszint általában gyengén fejlett. Borítása 20-30\%, magassága pedig 15-18 m. Állandó (K IV-V) fái ugyanazok, mint a felső 
lombkoronaszintben (Alnus glutinosa, Fraxinus angustifolia ssp. danubialis, Salix fragilis), de nagyobb tömeget egyikük sem ér el (1-2. táblázat).

A cserjeszint többnyire fejletlen. Borítása 1-25\%, magassága pedig 1,5-3 m. Állandó (K IV-V) fajai csak a Fraxinus angustifolia ssp. danubialis és a Salix cinerea. Jelentősebb tömeget (A-D 3-4) egyikük sem mutat. Az újulat borítása jelentéktelen: 1-3\%. Állandó (K IV) faja csak a Rubus caesius, de nagyobb tömeget (A-D 3-4) nem ér el (1-2. táblázat).

A gyepszint borítása 85-95\%. Viszonylag állandó (K IV-V) fajai a következők: Alisma plantago-aquatica, Calystegia sepium, Carex acutiformis, Carex riparia, Eupatorium cannabinum, Galium palustre, Lemna minor, Lycopus europaeus, Lysimachia vulgaris, Mentha aquatica, Oenanthe aquatica, Poa trivialis, Sium latifolium, Solanum dulcamara, Sparganium erectum, Stachys palustris, Symphytum officinale, Urtica dioica. Fáciesképző szerepet (A-D 3-4) csak a Carex acutiformis és a Carex riparia tölt be (1-2. táblázat).

\section{Fajkombináció}

Állandósági osztályok

A vizsgált égerlápokból az öt cönológiai felvétel alapján 14 konstans (K V) és 9 szubkonstans (K IV) faj került elö: - K V: Alnus glutinosa, Carex acutiformis, Carex riparia, Fraxinus angustifolia ssp. danubialis, Galium palustre, Lemna minor, Lycopus europaeus, Mentha aquatica, Oenanthe aquatica, Salix cinerea, Salix fragilis, Solanum

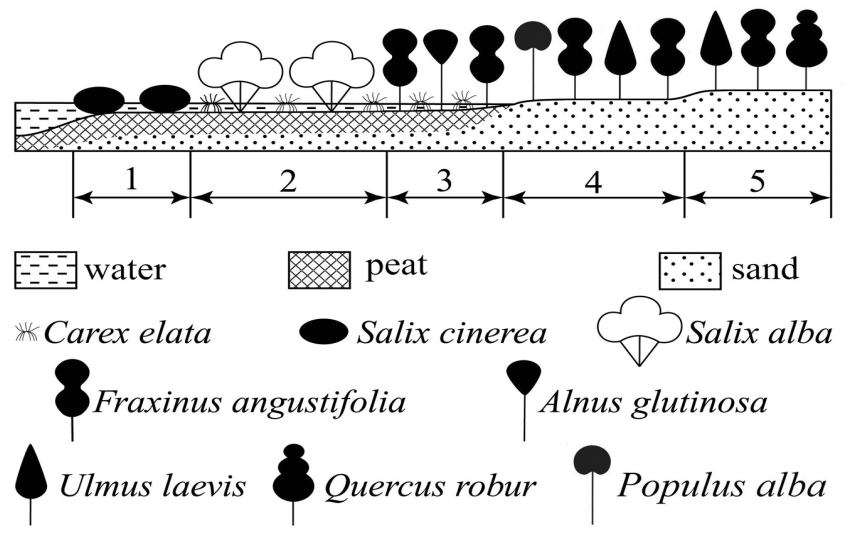

1. ábra: Részlet a Nyírség vegetáció-keresztmetszetéből (KEVEY in KEVEY et al. 2019) 1: rekettyefüzes füzláp (Calamagrostio-Salicetum cinereae); 2: fehérfüzes láperdő (Carici elatae-Salicetum albae); 3: magyar körises égerláp (Fraxino pannonicae-Alnetum glutinosae); 4: kiszáradó kőrisláp (Veratro albi-Fraxinetum angustifoliae); 5: tölgy-kőris-szil liget (Fraxino pannonicae-Ulmetum) 


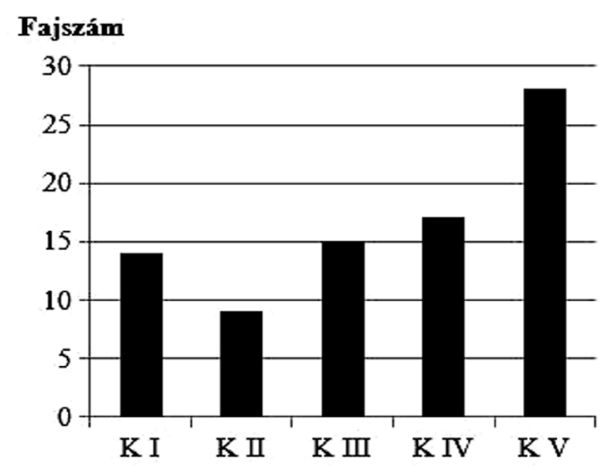

2. ábra: Állandósági osztályok eloszlása

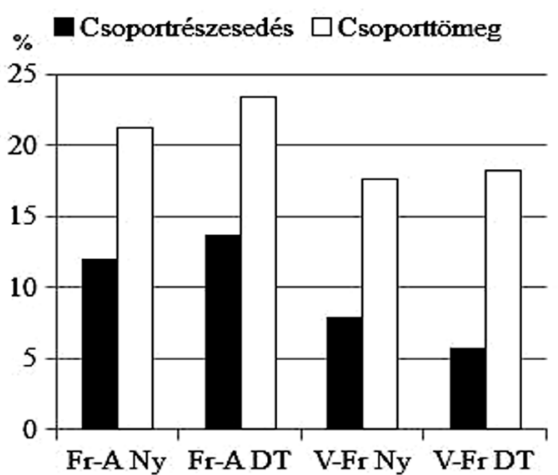

3. ábra: Alnetea fajok aránya

Fr-A Ny: Fraxino pannonicae-Alnetum glutinosae, Nyírség (Kevey - Papp ined.: 5 felv.); Fr-A DT: Fraxino pannonicae-Alnetum glutinosae, Duna-Tisza köze (Járai-Komlódi 1958: 25 felv.); V-Fr Ny: Veratro albi-Fraxinetum angustifoliae, Nyírség (Kevey et al. 2019: 10 felv.); V-Fr DT: Veratro albi-Fraxinetum angustifoliae, DunaTisza köze (Kevey 2020: 50 felv.)

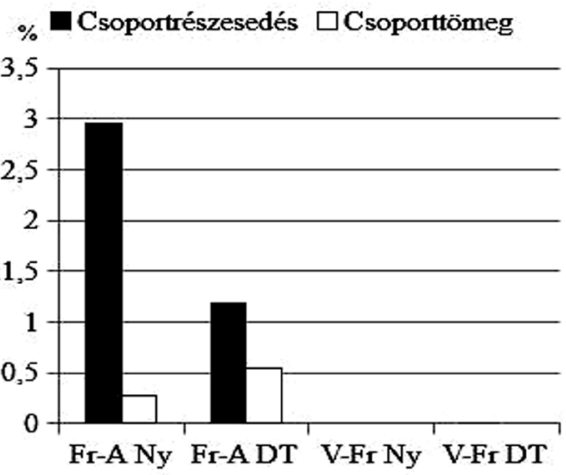

4. ábra: Lemno-Potamea s.l. fajok aránya

Fr-A Ny: Fraxino pannonicae-Alnetum glutinosae, Nyírség (Kevey - Papp ined.: 5 felv.); Fr-A DT: Fraxino pannonicae-Alnetum glutinosae, Duna-Tisza köze (Járai-Komlódi 1958: 25 felv.); V-Fr Ny: Veratro albi-Fraxinetum angustifoliae, Nyírség (Kevey et al. 2019: 10 felv.); V-Fr DT: Veratro albi-Fraxinetum angustifoliae, DunaTisza köze (Kevey 2020: 50 felv.) 


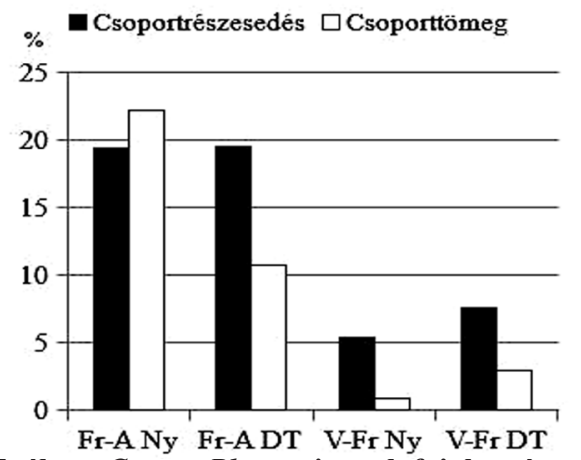

5. ábra: Cypero-Phragmitea s.l. fajok aránya

Fr-A Ny: Fraxino pannonicae-Alnetum glutinosae, Nyírség (Kevey - Papp ined.: 5 felv.); Fr-A DT: Fraxino pannonicae-Alnetum glutinosae, Duna-Tisza köze (Járai-Komlódi 1958: 25 felv.); V-Fr Ny: Veratro albi-Fraxinetum angustifoliae, Nyírség (Kevey et al. 2019: 10 felv.); V-Fr DT: Veratro albi-Fraxinetum angustifoliae, DunaTisza köze (Kevey 2020: 50 felv.)

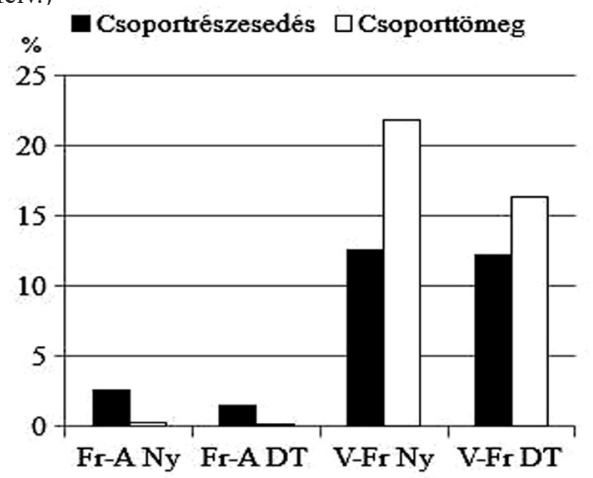

6. ábra: Querco-Fagetea fajok aránya

Fr-A Ny: Fraxino pannonicae-Alnetum glutinosae, Nyírség (Kevey - Papp ined.: 5 felv.); Fr-A DT: Fraxino pannonicae-Alnetum glutinosae, Duna-Tisza köze (Járai-Komlódi 1958: 25 felv.); V-Fr Ny: Veratro albi-Fraxinetum angustifoliae, Nyírség (Kevey et al. 2019: 10 felv.); V-Fr DT: Veratro albi-Fraxinetum angustifoliae, DunaTisza köze (Kevey 2020: 50 felv.)

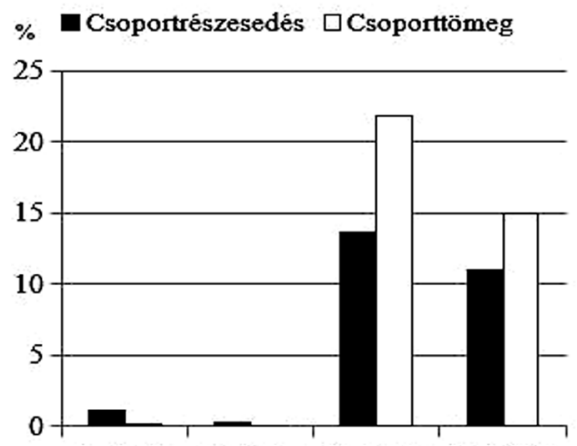

Fr-A Ny Fr-A DT V-Fr Ny V-FrDT

7. ábra: Quercetea pubescentis-petraeae fajok aránya

Fr-A Ny: Fraxino pannonicae-Alnetum glutinosae, Nyírség (Kevey - Papp ined.: 5 felv.); Fr-A DT: Fraxino pannonicae-Alnetum glutinosae, Duna-Tisza köze (Járai-Komlódi 1958: 25 felv.); V-Fr Ny: Veratro albi-Fraxinetum angustifoliae, Nyírség (Kevey et al. 2019: 10 felv.); V-Fr DT: Veratro albi-Fraxinetum angustifoliae, DunaTisza köze (Kevey 2020: 50 felv.) 
dulcamara, Stachys palustris, Symphytum officinale. - K IV: Alisma plantago-aquatica, Calystegia sepium, Eupatorium cannabinum, Lysimachia vulgaris, Poa trivialis, Rubus caesius, Sium latifolium, Sparganium erectum, Urtica dioica. A felvételi anyagban ezen kívül 15 akcesszórikus (K III), 17 szubakcesszórikus (K II) és 28 akcidens (K I) faj is szerepel (1. táblázat, 2. ábra). A fenti adatok szerint tehát az akcidens (K I) fajok mellett a konstans (K V) elemeknél van egy kiugró érték.

\section{Karakterfajok aránya}

A társulás felépítésében jelentős szerepet játszanak a láperdei (Alnetea glutinosae) elemek $11,94 \%$ csoportrészesedéssel és $21,29 \%$ csoporttömeggel: K V: Alnus glutinosa, Salix cinerea. - K III: Urtica kioviensis. - K I: Dryopteris carthusiana, Hottonia palustris (1. és 4. táblázat). Arányuk hasonló, mint a Duna-Tisza közének magyar kőrises égerlápjaiban (Fraxino pannonicae-Alnetum) és magasabb, mint a Nyírség és a DunaTisza köze kiszáradó kőrislápjaiban (Veratro albi-Fraxinetum angustifoliae) (4. táblázat, 3. ábra). Hasonló a helyzet a vízi növények (Lemno-Potamea s.1.) (4. ábra) és a mocsári növények (Cypero-Phragmitea s.1.) (5. ábra) esetében is (vö. 1. és 4. táblázat).

Ezzel ellentétes arányok mutatkoznak az általános lomberdei fajoknál (QuercoFagetea) (6. ábra) és a száraz tölgyesek elemeinél (Quercetea pubescentis-petraeae) (7. ábra), amelyek a kiszáradó kőrislápoknál (Veratro albi-Fraxinetum angustifoliae) érnek el nagyobb gyakoriságot (vö. 1. és 4. táblázat).

\section{Sokváltozós elemzések eredményei}

A Nyírség (Kevey - Papp ined.), és a Duna-Tisza köze vizsgált láperdeinek sokváltozós összehasonlításával mind a dendrogramon (8. ábra), mind pedig az ordinációs diagramon (9. ábra) egyértelmủen elkülönülnek a magyar körises égerlápok (Fraxino pannonicaeAlnetum) és a kiszáradó kőrislápok (Veratro albi-Fraxinetum angustifoliae).

\section{Természetvédelmi eredmények}

A Nyírség jelentős részét ma már kultúrerdők borítják. Ezek rengetegében a vizsgált magyar kőrises égerlápok (Fraxino pannonicae-Alnetum glutinosae) értékes mozaikként, mint oázisok különülnek el. E társulásból ugyan csak öt cönológiai felvételt sikerült készítenünk, de ezekböl öt védett növényfaj került elö: K III: Urtica kioviensis. - K II: Thelypteris palustris. - K I: Dryopteris carthusiana, Hottonia palustris, Listera ovata. Mellettük említésre méltó még a Nyírségben igen ritka Oenanthe banatica lokális előfordulása.

A vizsgált láperdők egyetlen felvételében fordul elö egy idegenhonos növényfaj, az Echynocystis lobata. Kicsiny egyedszámban él, ezért különös zavaró hatást nem fejt ki.

A Nyírábrányhoz tartozó „Mogyorósi-erdo”” a Hajdúsági Tájvédelmi Körzet része. Sajnos a Mérk melletti „Vadaskerti-erdő” mindeddig semmilyen védelemben nem részesült, pedig fokozott védelmet érdemelne.

\section{Diszkusszió}

A hagyományos statisztikai eredmények szépen alátámasztják azt, hogy mindkét homokvidékünkön (Nyírség, Duna-Tisza köze) a magyar kőrises égerlápok (Fraxino pannonicae-Alnetum glutinosae) feltöltődésével kiszáradó kőrislápok (Veratro nigriFraxinetum angustifoliae) jönnek létre. A két asszociáció a Nyírségben egymás mellett 


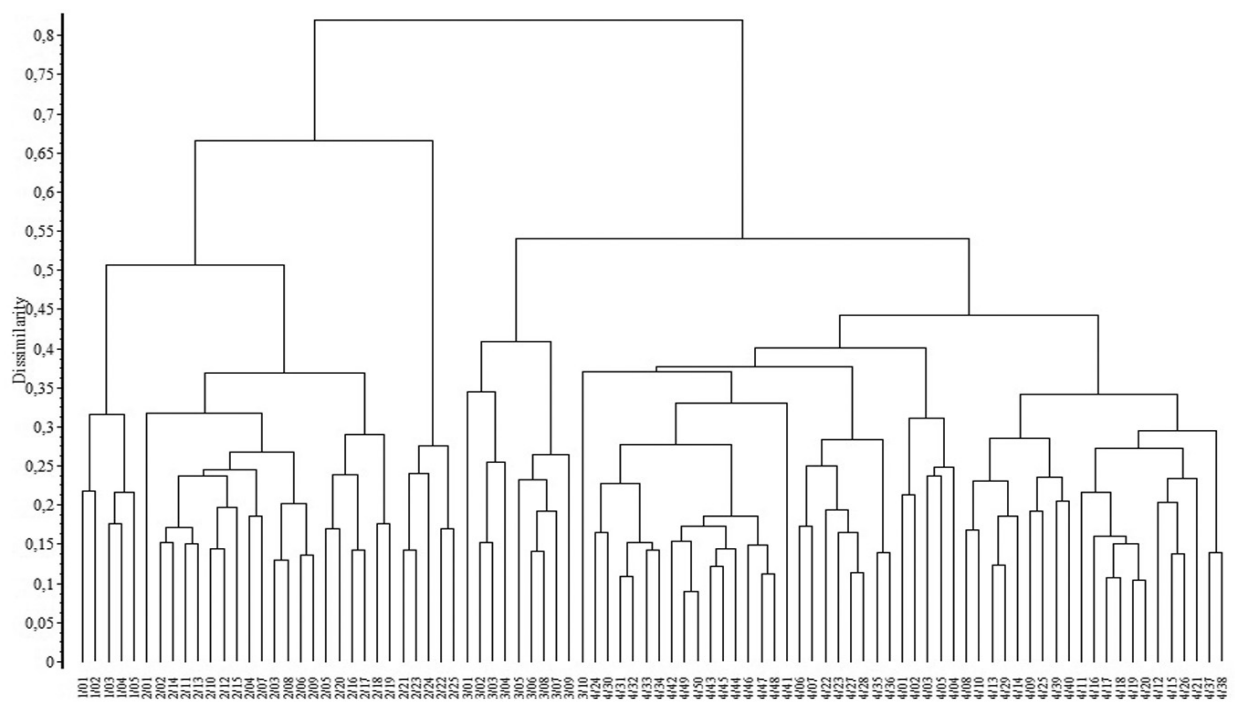

8. ábra: A Nyírség és a Duna-Tisza köze magyar kőrises égerlápjainak és kiszáradó kőrislápjainak dendrogramja. (hasonlósági index: Baroni-Urbani-Buser; osztályozó módszer: teljes lánc)

1/1-5: Fraxino pannonicae-Alnetum glutinosae Nyírség (Kevey - Papp ined.)

2/1-25: Fraxino pannonicae-Alnetum glutinosae Duna-Tisza köze (Járai-Komlódi 1958)

3/1-10: Veratro albi-Fraxinetum angustifoliae Nyírség (Kevey et al. 2019)

4/1-50: Veratro albi-Fraxinetum angustifoliae Duna-Tisza köze (Kevey 2020)

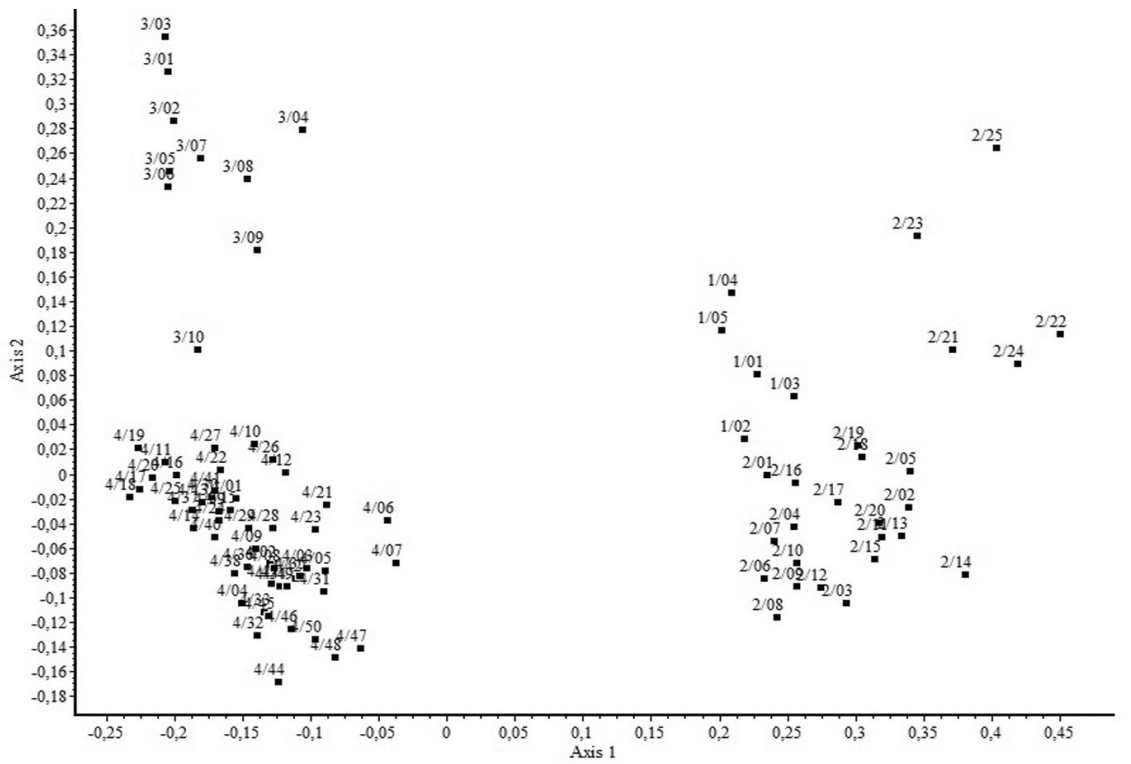

9. ábra: A Nyírség és a Duna-Tisza köze magyar kő́rises égerlápjainak és kiszáradó kőrislápjainak ordinációs diagramja (hasonlósági index: Baroni-Urbani-Buser; ordinációs módszer: foókoordináta-analízis)

1/1-5: Fraxino pannonicae-Alnetum glutinosae Nyírség (Kevey - Papp ined.)

2/1-25: Fraxino pannonicae-Alnetum glutinosae Duna-Tisza köze (Járai-Komlódi 1958)

3/1-10: Veratro albi-Fraxinetum angustifoliae Nyírség (Kevey et al. 2019)

4/1-50: Veratro albi-Fraxinetum angustifoliae Duna-Tisza köze (Kevey 2020) 
megtalálható a Nyírábrány feletti „Mogyorósi-erdő”-ben (1. ábra), valamint a DunaTisza közének számos pontján.

A dendrogramon (8. ábra) a Duna-Tisza közi felvételekből öt magyar kőrises égerláp (Fraxino pannonicae-Alnetum glutinosae) felvétel kissé elkülönülő csoportot képez. Ugyanez figyelhető meg az ordinációs diagramon is (9. ábra). Ezek a felvételek némi átmenetet jeleznek a kiszáradó kőrislápok (Veratro nigri-Fraxinetum angustifoliae) felé. A kiszáradó kőrislápok nyírségi és Duna-Tisza közi felvételei ezzel szemben egyértelmü csoportot alkotnak (8-9. ábra).

Összegezve a fentieket, a Nyírség fragmentális magyar kőrises égerlápjai a DunaTisza közéröl leírt Fraxino pannonicae-Alnetum glutinosae asszociációval azonosíthatóak. Szüntaxonómiai helye az alábbi módon vázolható:

Divisio: Querco-Fagea Jakucs 1967

Classis: Alnetea Glutinosae Br.-Bl. et Tx. ex Westhoff et al. 1946

Ordo: Alnetalia glutinosae Tx 1937

Alliance: Alnion glutinosae Malcuit 1929

Suballiance: Carici elongatae-Alnenion glutinosae Kevey 2008

Associatio: Fraxino pannonicae-Alnetum glutinosae Soó et Járai-Komlódi in Járai-Komlódi 1958

\section{Összefoglalás}

Jelen tanulmány öt cönológiai felvétellel mutatja be a Nyírség homokvidékén igen ritka égerlápokat, amelyekből olyan ritka fajok kerültek elö, mint az Urtica kioviensis, a Thelypteris palustris, a Hottonia palustris, a Dryopteris carthusiana, a Listera ovata és az Oenanthe banatica. A felmért állományok a Duna-Tisza közéről leírt magyar kőrises égerlápokkal (Fraxino pannonicae-Alnetum glutinosae Soó et Járai-Komlódi in JáraiKomlódi 1958) azonosíthatók.

\section{Rövidítések}

A1: felső lombkoronaszint; A2: alsó lombkoronaszint; Adv: Adventiva; Agi: Alnenion glutinosae-incanae; Ai: Alnion incanae; Alo: Alopecurion pratensis; Aon: Alnion glutinosae; AQ: Aceri tatarici-Quercion; Arc: Arction lappae; Ata: Alnetalia glutinosae; B1: cserjeszint; B2: újulat; Ber: Berberidion; Bia: Bidentetalia; Bon: Bidention tripartiti; C: gyepszint; Cgr: Caricenion gracilis; Che: Chenopodietea; Chr: Chenopodion rubri; ChS: Chenopodio-Scleranthea; Cn: Calystegion sepium; Cp: Carpinenion betuli; Cro: Caricenion rostratae; Des: Deschampsion caespitosae; Epa: Epilobietalia; F: Fagetalia sylvaticae; FPe: FestucoPuccinellietea; FPi: Festuco-Puccinellietalia; GA: Galio-Alliarion; GSp: Glycerio-Sparganion; Hya: Hydrocharietalia; I: Indifferens; ined.: ineditum (kiadatlan közlés); Le: Lemnion minoris; LeP: LemnoPotamea; Mag: Magnocaricion; Moa: Molinietalia coeruleae; MoA: Molinio-Arrhenatherea; Moa: MolinioJuncetea; Ncn: Nanocyperion flavescentis; Pea: Potametea; Phn: Phragmition; Pla: Plantaginetalia majoris; Pon: Potamion; PQ: Pino-Quercion; Pte: Phragmitetea; Qc: Quercetalia cerridis; QFt: Querco-Fagetea; Qpp: Quercetea pubescentis-petraeae; Qr: Quercetalia roboris; S: summa (összeg); Sal: Salicion albae; SaS: Sambuco-Salicion capreae; SCn: Scheuchzerio-Caricetalia nigrae; Sea: Secalietea; s.1.: sensu lato (tágabb értelemben); Spu: Salicetalia purpureae; Ulm: Ulmenion; VP: Vaccinio-Piceetea. 


\section{1. táblázat: Fraxino pannonicae-Alnetum}

\begin{tabular}{|c|c|c|c|c|c|c|c|c|c|}
\hline \multirow[b]{2}{*}{\begin{tabular}{|l} 
1/1. táblázat \\
1. Querco-Fagea \\
1.1. Salicetea purpureae \\
1.1.1. Salicetalia purpureae \\
1.1.1.1. Salicion albae
\end{tabular}} & Szint & 1 & 2 & 3 & 4 & 5 & A-D & $\mathbf{K}$ & $\mathbf{K} \%$ \\
\hline & & & & & & & & & \\
\hline \multirow[t]{3}{*}{ Salix fragilis $(\mathrm{Ai}, \mathrm{Cn})$} & A1 & 1 & + & 1 & 1 & - & +-1 & IV & 80 \\
\hline & $\mathrm{A} 2$ & 1 & + & 1 & 1 & 1 & +-1 & $\mathrm{~V}$ & 100 \\
\hline & $\mathrm{S}$ & 2 & + & 2 & 2 & 1 & +-2 & $\mathrm{~V}$ & 100 \\
\hline \multirow[t]{3}{*}{ Salix alba (Ai, Cn) } & A1 & - & - & 1 & + & 1 & +-1 & III & 60 \\
\hline & A2 & - & - & 1 & - & - & 1 & I & 20 \\
\hline & $\mathrm{S}$ & - & - & 2 & + & 1 & +-2 & III & 60 \\
\hline Carduus crispus (Cn) & $\mathrm{C}$ & - & - & - & + & - & + & $\mathrm{I}$ & 20 \\
\hline \multicolumn{10}{|l|}{$\begin{array}{l}\text { 1.2. Alnetea glutinosae } \\
\text { 1.2.1. Alnetalia glutinosae }\end{array}$} \\
\hline \multirow[t]{4}{*}{ Alnus glutinosa (Ai, Agi) } & A1 & 1 & 3 & 2 & 4 & 4 & $1-4$ & $\mathrm{~V}$ & 100 \\
\hline & A2 & - & 1 & 2 & 2 & 1 & $1-2$ & IV & 80 \\
\hline & B1 & - & - & + & + & - & + & II & 40 \\
\hline & $\mathrm{S}$ & 1 & 3 & 3 & 5 & 4 & $1-5$ & $\mathrm{~V}$ & 100 \\
\hline \multirow[t]{3}{*}{ Salix cinerea (Pte, Aon, Ai) } & B1 & 2 & 2 & 2 & + & + & +-2 & $\mathrm{~V}$ & 100 \\
\hline & B2 & - & + & - & - & - & + & I & 20 \\
\hline & $\mathrm{S}$ & 2 & 2 & 2 & + & + & +-2 & $\mathrm{~V}$ & 100 \\
\hline Urtica kioviensis & $\mathrm{C}$ & - & - & + & + & + & + & III & 60 \\
\hline Dryopteris carthusiana (F, Agi, Qr, VP) & $\mathrm{C}$ & - & - & - & - & + & + & I & 20 \\
\hline Hottonia palustris (Pon) & $\mathrm{C}$ & + & - & - & - & - & + & I & 20 \\
\hline \multicolumn{10}{|l|}{ 1.2.1.1. Alnion glutinosae } \\
\hline Thelypteris palustris (Mag) & $\mathrm{C}$ & - & 2 & - & - & + & +-2 & II & 40 \\
\hline \multicolumn{10}{|l|}{ 1.3. Querco-Fagetea } \\
\hline Ajuga reptans (MoA) & $\mathrm{C}$ & - & - & - & + & + & + & II & 40 \\
\hline Brachypodium sylvaticum (Qpp) & $\mathrm{C}$ & - & + & - & + & - & + & II & 40 \\
\hline \multirow[t]{3}{*}{ Cornus sanguinea (Qpp) } & B1 & - & + & - & + & - & + & II & 40 \\
\hline & B2 & - & + & - & - & - & + & I & 20 \\
\hline & $\mathrm{S}$ & - & + & - & + & - & + & II & 40 \\
\hline \multirow[t]{3}{*}{ Populus tremula (Qr, Qc, Ber) } & A2 & - & - & - & + & - & + & $\mathrm{I}$ & 20 \\
\hline & B2 & - & - & - & + & - & + & I & 20 \\
\hline & $\mathrm{S}$ & - & - & - & + & - & + & I & 20 \\
\hline Quercus robur (Ai, Cp, Qpp) & $\mathrm{B} 2$ & - & - & - & - & + & + & I & 20 \\
\hline Ranunculus ficaria & $\mathrm{C}$ & - & - & - & - & + & + & I & 20 \\
\hline $\begin{array}{l}\text { Ulmus minor (Ai, Ulm, Qpp) } \\
\text { 1.3.1. Fagetalia sylvaticae }\end{array}$ & B2 & - & - & + & - & - & + & I & 20 \\
\hline Listera ovata (Ata, Ai) & $\mathrm{C}$ & - & - & - & - & + & + & $\mathrm{I}$ & 20 \\
\hline
\end{tabular}




\section{1. táblázat: Fraxino pannonicae-Alnetum}

\begin{tabular}{|c|c|c|c|c|c|c|c|c|c|}
\hline \multirow{2}{*}{\multicolumn{2}{|c|}{$\begin{array}{|cc|}1 / 2 \text {. táblázat } & \text { Szint } \\
13.1 \text { Alnion incanae }\end{array}$}} & \multirow[t]{2}{*}{1} & \multirow[t]{2}{*}{2} & \multirow[t]{2}{*}{3} & \multirow{2}{*}{\multicolumn{2}{|c|}{4}} & \multicolumn{3}{|c|}{ A-D K K\% } \\
\hline & & & & & & & & & \\
\hline \multirow[t]{5}{*}{ Fraxinus angustifolia ssp. danubialis (Ata) } & A1 & 3 & 3 & 3 & 2 & 2 & $2-3$ & $\mathrm{~V}$ & 100 \\
\hline & A2 & 2 & 2 & 1 & 2 & 2 & $1-2$ & $\mathrm{~V}$ & 100 \\
\hline & B1 & + & - & + & + & 1 & +-1 & IV & 80 \\
\hline & $\mathrm{B} 2$ & + & - & - & + & 1 & +-1 & III & 60 \\
\hline & $\mathrm{S}$ & 4 & 4 & 3 & 3 & 3 & $3-4$ & $\mathrm{~V}$ & 100 \\
\hline Carex remota & $\mathrm{C}$ & - & - & + & + & + & + & III & 60 \\
\hline Festuca gigantea (Cn, Epa) & $\mathrm{C}$ & - & + & - & + & + & + & III & 60 \\
\hline \multirow[t]{3}{*}{ Frangula alnus (Ata, Qr, PQ) } & B 1 & + & - & + & - & - & + & II & 40 \\
\hline & $\mathrm{B} 2$ & - & + & - & - & - & + & I & 20 \\
\hline & $\mathrm{S}$ & + & + & + & - & - & + & III & 60 \\
\hline Impatiens noli-tangere (Sal) & $\mathrm{C}$ & - & - & + & + & + & + & III & 60 \\
\hline \multirow[t]{4}{*}{ Populus alba (Sal, AQ) } & A1 & - & 1 & - & - & - & 1 & I & 20 \\
\hline & B 1 & - & - & - & + & - & + & I & 20 \\
\hline & $\mathrm{B} 2$ & + & - & - & - & - & + & I & 20 \\
\hline & $\mathrm{S}$ & + & 1 & - & + & - & +-1 & III & 60 \\
\hline Viburnum opulus (Ata) & B2 & + & - & + & - & - & + & II & 40 \\
\hline Oenanthe banatica & $\mathrm{C}$ & - & - & - & - & + & + & I & 20 \\
\hline \multicolumn{10}{|l|}{ 2. Lemno-Potamea } \\
\hline Lemna minor (Hya, Le) & $\mathrm{C}$ & + & + & + & + & + & + & $\mathrm{V}$ & 100 \\
\hline \multicolumn{10}{|l|}{$\begin{array}{l}\text { 3. Cypero-Phragmitea } \\
\text { 3.1. Phragmitetea }\end{array}$} \\
\hline Carex acutiformis (Mag, Cgr, Moa, Sal, Ata) & $\mathrm{C}$ & 2 & 3 & 2 & 2 & 3 & $2-3$ & $\mathrm{~V}$ & 100 \\
\hline Carex riparia (Mag, Cgr, Moa, Sal, Ata) & $\mathrm{C}$ & 4 & 3 & 3 & 4 & 3 & $3-4$ & $\mathrm{~V}$ & 100 \\
\hline Galium palustre (Mag, Moa, FPi, Spu, Ata) & $\mathrm{C}$ & + & + & 1 & + & 1 & +-1 & $\mathrm{~V}$ & 100 \\
\hline Lycopus europaeus (Moa, Cn, Bia, Spu, Ata) & $\mathrm{C}$ & + & + & + & + & + & + & $\mathrm{V}$ & 100 \\
\hline Oenanthe aquatica (Spu, Ata) & $\mathrm{C}$ & + & + & + & + & + & + & $\mathrm{V}$ & 100 \\
\hline \multirow[t]{3}{*}{ Solanum dulcamara (Cn, Bia, Spu) } & B1 & + & - & + & - & + & + & III & 60 \\
\hline & $\mathrm{C}$ & 2 & + & 1 & 1 & 1 & +-2 & $\mathrm{~V}$ & 100 \\
\hline & $\mathrm{S}$ & 2 & + & 1 & 1 & 1 & +-2 & $\mathrm{~V}$ & 100 \\
\hline Stachys palustris (Moa, Cn, Bon, Spu, Ata) & $\mathrm{C}$ & + & 1 & + & + & 1 & +-1 & $\mathrm{~V}$ & 100 \\
\hline Alisma plantago-aquatica (Pea, Spu, Ata, LeP) & $\mathrm{C}$ & + & - & + & + & + & + & IV & 80 \\
\hline Eupatorium cannabinum (Epa, Sal, Ata, Ai) & $\mathrm{C}$ & + & + & + & - & + & + & IV & 80 \\
\hline Sium latifolium (Sal, Ata) & $\mathrm{C}$ & + & - & + & + & 1 & +-1 & IV & 80 \\
\hline Sparganium erectum (Phn, GSp, Ata) & $\mathrm{C}$ & + & + & 1 & + & - & +-1 & IV & 80 \\
\hline Glyceria maxima (Phn, Spu) & $\mathrm{C}$ & - & - & 2 & + & + & +-2 & III & 60 \\
\hline Iris pseudacorus (Sal, Ata, Ai) & $\mathrm{C}$ & + & 1 & - & + & - & +-1 & III & 60 \\
\hline Scutellaria galericulata (Moa, Spu, Ata) & $\mathrm{C}$ & + & + & - & - & + & + & III & 60 \\
\hline Myosotis scorpioides (Moa, Spu, Ata, Cn) & $\mathrm{C}$ & + & - & - & + & - & + & II & 40 \\
\hline Poa palustris (Moa, Des, Spu, Ata, Ai) & $\mathrm{C}$ & - & + & - & + & - & + & II & 40 \\
\hline Rorippa amphibia (Pla, Spu, Ata) & $\mathrm{C}$ & + & - & + & - & - & + & II & 40 \\
\hline Typha latifolia (Phn) & $\mathrm{C}$ & - & - & + & + & - & + & II & 40 \\
\hline Epilobium parviflorum (GSp, Moa, Moa, Ata) & $\mathrm{C}$ & - & - & - & - & + & + & I & 20 \\
\hline Equisetum palustre (Moa, Moa, Spu, Ata, Ai) & $\mathrm{C}$ & - & + & - & - & - & + & $\mathrm{I}$ & 20 \\
\hline
\end{tabular}


1. táblázat: Fraxino pannonicae-Alnetum

\begin{tabular}{|c|c|c|c|c|c|c|c|c|c|}
\hline 1/3. táblázat & Szint & 1 & 2 & 3 & 4 & 5 & A-D & $\mathbf{K}$ & $\mathbf{K} \%$ \\
\hline Phragmites australis (Moa, FPe, Spu, Ata) & $\mathrm{C}$ & 1 & - & - & - & - & 1 & I & 20 \\
\hline Rumex hydrolapathum (Ata) & $\mathrm{C}$ & - & + & - & - & - & + & I & 20 \\
\hline $\begin{array}{l}\text { Veronica anagallis-aquatica }(\mathrm{GSp}, \mathrm{Nen}, \mathrm{Bia}) \\
\text { 3.1.1. Phragmitetalia } \\
\text { 3.1.2. Nasturtio-Glycerietalia } \\
\text { 3.1.2.1. Glycerio-Sparganion }\end{array}$ & $\mathrm{C}$ & - & - & - & - & + & + & I & 20 \\
\hline $\begin{array}{l}\text { Scrophularia umbrosa }(\mathrm{Ai}) \\
\text { 3.1.3. Magnocaricetalia } \\
\text { 3.1.3.1. Magnocaricion }\end{array}$ & $\mathrm{C}$ & - & + & - & - & - & + & I & 20 \\
\hline Carex vesicaria (Cgr, Ata) & $\mathrm{C}$ & - & - & 2 & 1 & 1 & $1-2$ & III & 60 \\
\hline Carex otrubae (Cgr, Moa, FPi, Ai) & $\mathrm{C}$ & - & - & + & - & + & + & II & 40 \\
\hline $\begin{array}{l}\text { Teucrium scordium (Des) } \\
\text { 3.1.3.1.1. Caricenion rostratae }\end{array}$ & $\mathrm{C}$ & - & - & 1 & + & - & +-1 & II & 40 \\
\hline $\begin{array}{l}\text { Carex elata (Mag, Moa, Ata) } \\
\text { 4. Molinio-Arrhenatherea }\end{array}$ & $\mathrm{C}$ & - & - & - & + & - & + & I & 20 \\
\hline Poa trivialis (Pte, $\mathrm{Spu}, \mathrm{Ata}, \mathrm{Ai}$ ) & $\mathrm{C}$ & + & + & - & + & + & + & IV & 80 \\
\hline $\begin{array}{l}\text { Cardamine pratensis (Mag, Des, Sal, Ata, Ai) } \\
\text { 4.1. Molinio-Juncetea }\end{array}$ & $\mathrm{C}$ & - & - & + & + & + & + & III & 60 \\
\hline Symphytum officinale (Pte, Cn, Spu, Ata, Ai) & $\mathrm{C}$ & + & + & 1 & 1 & + & +-1 & $\mathrm{~V}$ & 100 \\
\hline Deschampsia caespitosa (Des, Sal, Ata, Ai) & $\mathrm{C}$ & + & - & - & - & - & + & I & 20 \\
\hline $\begin{array}{l}\text { Galium uliginosum (Mag, Ata) } \\
\text { 4.1.1. Molinietalia coeruleae }\end{array}$ & $\mathrm{C}$ & + & - & - & - & - & + & $\mathrm{I}$ & 20 \\
\hline $\begin{array}{l}\text { Angelica sylvestris (Mag, Ata, Ai) } \\
\text { 5. Chenopodio-Scleranthea }\end{array}$ & $\mathrm{C}$ & - & + & - & - & - & + & I & 20 \\
\hline $\begin{array}{l}\text { Chenopodium polyspermum (Bia, Chr) } \\
\text { 5.1. Chenopodietea }\end{array}$ & $\mathrm{C}$ & - & - & - & + & + & + & II & 40 \\
\hline $\begin{array}{l}\text { Arctium minus (Arc, Bia, Pla) } \\
\text { 5.2. Galio-Urticetea } \\
\text { 5.2.1. Calystegietalia sepium } \\
\text { 5.2.1.1. Calystegion sepium }\end{array}$ & $\mathrm{C}$ & + & - & - & - & - & + & I & 20 \\
\hline Calystegia sepium (Pte, Bia, Pla, Spu, & $\begin{array}{l}\text { B1 } \\
\text { C } \\
\text { S }\end{array}$ & $\begin{array}{l}- \\
-\end{array}$ & $\begin{array}{l}+ \\
+ \\
+\end{array}$ & $\begin{array}{l}- \\
1 \\
1\end{array}$ & $\begin{array}{l}- \\
+ \\
+\end{array}$ & $\begin{array}{l}- \\
1 \\
1\end{array}$ & $\begin{array}{c}+ \\
+-1 \\
+-1\end{array}$ & $\begin{array}{l}\text { I } \\
\text { IV } \\
\text { IV }\end{array}$ & $\begin{array}{l}20 \\
80 \\
80\end{array}$ \\
\hline $\begin{array}{l}\text { Myosoton aquaticum (Pte, } \mathrm{Spu}, \mathrm{Ata}, \mathrm{Ai}) \\
\text { 5.3. Bidentetea } \\
\text { 5.3.1. Bidentetalia }\end{array}$ & $\mathrm{C}$ & + & - & - & + & - & + & II & 40 \\
\hline Bidens tripartita (Pte, Ncn, Sea, Sal) & $\mathrm{C}$ & - & - & + & + & + & + & III & 60 \\
\hline Persicaria hydropiper (Nen, Bon, Spu, Ata, Ai) & $\mathrm{C}$ & - & - & 1 & - & + & +-1 & II & 40 \\
\hline $\begin{array}{l}\text { Persicaria dubia (Alo, Bon, } \mathrm{Spu}, \mathrm{Ai} \text { ) } \\
\text { 5.4. Epilobietea angustifolii } \\
\text { 5.4.1. Epilobietalia }\end{array}$ & $\mathrm{C}$ & - & - & - & + & - & + & I & 20 \\
\hline Galeopsis bifida (Cn) & $\mathrm{C}$ & - & - & - & - & + & + & $\mathrm{I}$ & 20 \\
\hline
\end{tabular}




\section{1. táblázat: Fraxino pannonicae-Alnetum}

\begin{tabular}{|c|c|c|c|c|c|c|c|c|c|}
\hline $1 / 4 . t$ & Szint & 1 & 2 & 3 & 4 & 5 & A-D & $\mathbf{K}$ & $\mathbf{K} \%$ \\
\hline \multicolumn{10}{|l|}{ 6. Indifferens } \\
\hline Mentha aquatica (Pte, Moa, Spu, Ata, Ai) & $\mathrm{C}$ & + & 1 & + & 1 & + & +-1 & $\mathrm{~V}$ & \\
\hline Lysimachia vulgaris (Ai, Pte, SCn, Moa, Sal) & $\mathrm{C}$ & + & - & + & + & + & + & IV & \\
\hline Rubu & B2 & + & - & + & + & + & + & IV & 80 \\
\hline Urtic & $\mathrm{C}$ & + & + & - & + & 1 & +-1 & $\mathrm{~V}$ & 30 \\
\hline Lythrt & $\mathrm{C}$ & - & + & + & + & - & + & III & \\
\hline Ranunculus repens (Pte, MoA, ChS, Spu, Ata) & $\mathrm{C}$ & + & + & - & - & + & + & III & \\
\hline Caltha palustris (Mag, Moa, Spu, Ata, Ai) & $\mathrm{C}$ & + & + & - & - & - & + & II & \\
\hline Glechoma hederacea (MoA, QFt, Sal, Ai) & $\mathrm{C}$ & + & - & - & + & - & + & II & 40 \\
\hline ularia (Pte, Moa, Bia) & $\mathrm{C}$ & - & - & - & + & + & + & II & 40 \\
\hline Equisetum arvense (MoA, Sea, Sal, Ata, Ai) & $\mathrm{C}$ & - & + & - & - & - & + & I & 2 \\
\hline Galium aparine (Sea, Epa, QFt) & $\mathrm{C}$ & - & - & - & - & + & + & I & 20 \\
\hline Ranunculus sceleratus (Pte, Ncn, Bia, Bon, Sal) & $\mathrm{C}$ & - & - & - & - & + & + & I & 2 \\
\hline Sambucus nigra (Epa, SaS, QFt) & B1 & - & - & - & - & + & + & I & 2 \\
\hline Echinocystis lobata & $\mathrm{C}$ & + & - & - & - & - & + & I & \\
\hline
\end{tabular}

2. táblázat: Felvételi adatok I.

\begin{tabular}{|l|c|c|c|c|c|}
\hline & $\mathbf{1}$ & $\mathbf{2}$ & $\mathbf{3}$ & $\mathbf{4}$ & $\mathbf{5}$ \\
\hline Kvadrát felvételi sorszáma & 5936 & 15812 & 12631 & 15813 & 15814 \\
Felvételi évszám 1. & 2004 & 2007 & 2004 & 2007 & 2007 \\
Felvételi időpont 1. & 04.26 & 04.23 & 06.27 & 04.23 & 04.23 \\
Felvételi évszám 2. & 2004 & 2007 & 2007 & 2007 & 2007 \\
Felvételi időpont 2. & 06.26 & 08.11 & 04.23 & 08.11 & 08.11 \\
Tengerszint feletti magasság & 146 & 147 & 123 & 123 & 123 \\
Lejtőszög (fok) & 0 & 0 & 0 & 0 & 0 \\
Felső lombkoronaszint borítása (\%) & 60 & 65 & 60 & 70 & 70 \\
Felső lombkoronaszint magassága (m) & 25 & 22 & 20 & 22 & 25 \\
Átlagos törzsátmérő (cm) & 50 & 45 & 45 & 35 & 40 \\
Alsó lombkoronaszint borítása (\%) & 20 & 20 & 30 & 30 & 25 \\
Alsó lombkoronaszint magassága (m) & 18 & 15 & 15 & 16 & 18 \\
Cserjeszint borítása (\%) & 20 & 25 & 10 & 1 & 5 \\
Cserjeszint magassága (m) & 2,5 & 3 & 2,5 & 1,5 & 1,5 \\
Újulat borítása (\%) & 1 & 1 & 1 & 1 & 3 \\
Gyepszint borítása (\%) & 90 & 95 & 85 & 90 & 85 \\
Felvételi terület nagysága (m ${ }^{2}$ ) & 1200 & 1200 & 1600 & 1600 & 1600 \\
\hline
\end{tabular}




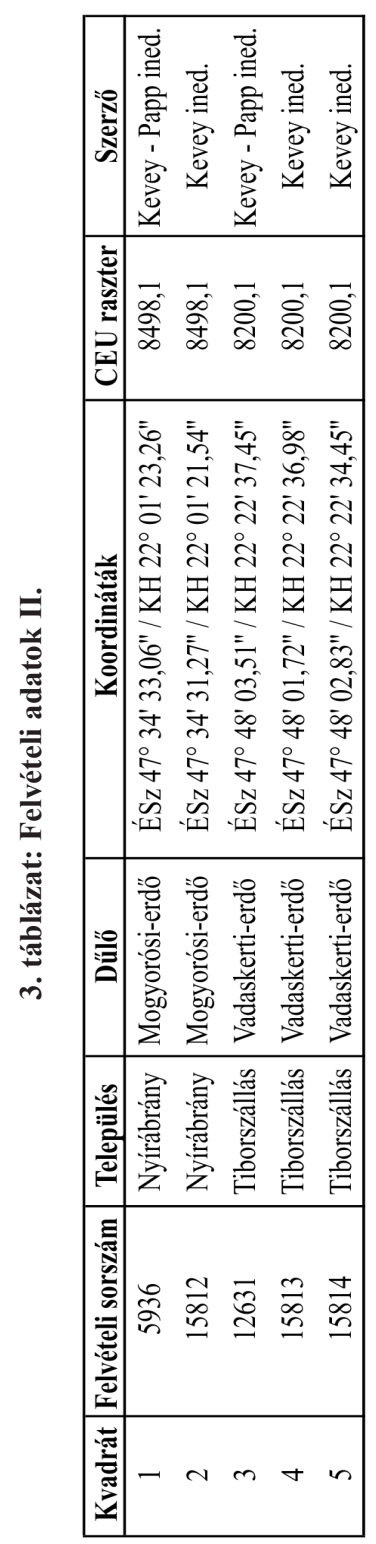




\section{4. táblázat: Karakterfajok aránya}

\begin{tabular}{|c|c|c|c|c|c|c|c|c|}
\hline 4/1. táblázat & Fr-A Ny & $\begin{array}{l}\text { Csoportré } \\
\text { Fr-A DT }\end{array}$ & $\begin{array}{l}\text { zzesedés } \\
\text { V-Fr Ny }\end{array}$ & V-Fr DT & \multicolumn{4}{|c|}{ Csoporttömeg } \\
\hline Querco-Fagea & 0,00 & 0,00 & 0,00 & 0,00 & 0,00 & 0,00 & 0,00 & 0,00 \\
\hline Salicetea purpureae & 0,00 & 0,00 & 0,00 & 0,00 & 0,00 & 0,00 & 0,00 & 0,00 \\
\hline Salicetalia purpureae & 6,01 & 4,25 & 1,47 & 2,09 & 1,69 & 3,64 & 0,45 & 2,96 \\
\hline Salicion albae & 4,73 & 3,48 & 3,18 & 2,98 & 2,48 & 1,89 & 2,62 & 2,23 \\
\hline Populenion nigro-albae & 0,00 & 0,00 & 0,49 & 0,62 & 0,00 & 0,00 & 0,06 & 0,14 \\
\hline Salicion albae s.l. & 4,73 & 3,48 & 3,67 & 3,60 & 2,48 & 1,89 & 2,68 & 2,37 \\
\hline Salicetalia purpureae s.l. & 10,74 & 7,73 & 5,14 & 5,69 & 4,17 & 5,53 & 3,13 & 5,33 \\
\hline Salicetea purpureae s.l. & 10,74 & 7,73 & 5,14 & 5,69 & 4,17 & 5,53 & 3,13 & 5,33 \\
\hline Alnetea glutinosae & 0,00 & 0,00 & 0,00 & 0,00 & 0,00 & 0,00 & 0,00 & 0,00 \\
\hline Alnetalia glutinosae & 10,88 & 11,77 & 7,07 & 5,60 & 19,60 & 20,93 & 17,51 & 18,19 \\
\hline Alnion glutinosae & 1,06 & 1,91 & 0,83 & 0,08 & 1,69 & 2,45 & 0,10 & 0,01 \\
\hline Alnetalia glutinosae s.l. & 11,94 & 13,68 & 7,90 & 5,68 & 21,29 & 23,38 & 17,61 & 18,20 \\
\hline Alnetea glutinosae s.l. & 11,94 & 13,68 & 7,90 & 5,68 & 21,29 & 23,38 & 17,61 & 18,20 \\
\hline Querco-Fagetea & 2,65 & 1,53 & 12,66 & 12,21 & 0,25 & 0,20 & 21,83 & 16,34 \\
\hline Fagetalia sylvaticae & 0,25 & 0,47 & 3,92 & 1,38 & 0,02 & 0,06 & 0,72 & 0,54 \\
\hline Alnion incanae & 9,66 & 7,16 & 7,82 & 6,89 & 20,70 & 19,61 & 20,37 & 20,11 \\
\hline Alnenion glutinosae-incanae & 0,88 & 1,28 & 0,00 & 0,03 & 6,67 & 12,71 & 0,00 & 0,17 \\
\hline Ulmenion & 0,12 & 0,47 & 0,77 & 1,01 & 0,01 & 0,10 & 0,89 & 1,12 \\
\hline Alnion incanae s.l. & 10,66 & 8,91 & 8,59 & 7,93 & 27,38 & 32,42 & 21,26 & 21,40 \\
\hline Fagion sylvaticae & 0,00 & 0,00 & 0,00 & 0,00 & 0,00 & 0,00 & 0,00 & 0,00 \\
\hline Carpinenion betuli & 0,12 & 0,00 & 2,52 & 1,54 & 0,01 & 0,00 & 2,73 & 1,69 \\
\hline Tilio-Acerenion & 0,00 & 0,00 & 0,00 & 0,06 & 0,00 & 0,00 & 0,00 & 0,01 \\
\hline Fagion sylvaticae s.l. & 0,12 & 0,00 & 2,52 & 1,60 & 0,01 & 0,00 & 2,73 & 1,70 \\
\hline Fagetalia sylvaticae s.l. & 11,03 & 9,38 & 15,03 & 10,91 & 27,41 & 32,48 & 24,71 & 23,64 \\
\hline Quercetalia roboris & 0,56 & 0,93 & 0,62 & 0,68 & 0,05 & 0,20 & 0,12 & 0,44 \\
\hline Quercion robori-petraeae & 0,00 & 0,00 & 0,18 & 0,42 & 0,00 & 0,00 & 0,02 & 0,04 \\
\hline Quercetalia roboris s.1. & 0,56 & 0,93 & 0,80 & 1,10 & 0,05 & 0,20 & 0,14 & 0,48 \\
\hline Querco-Fagetea s.l. & 14,24 & 11,84 & 28,49 & 24,22 & 27,71 & 32,88 & 46,68 & 40,46 \\
\hline Quercetea pubescentis-petraeae & 1,17 & 0,31 & 13,67 & 11,03 & 0,11 & 0,04 & 21,89 & 14,98 \\
\hline Quercetalia cerridis & 0,12 & 0,00 & 0,45 & 0,56 & 0,01 & 0,00 & 0,10 & 0,35 \\
\hline Aceri tatarici-Quercion & 0,47 & 0,00 & 0,78 & 0,31 & 0,12 & 0,00 & 1,66 & 1,04 \\
\hline Quercetalia cerridis s.1. & 0,59 & 0,00 & 1,23 & 0,87 & 0,13 & 0,00 & 1,76 & 1,39 \\
\hline Prunetalia spinosae & 0,00 & 0,00 & 1,11 & 1,03 & 0,00 & 0,00 & 0,17 & 0,60 \\
\hline Berberidion & 0,12 & 0,00 & 0,20 & 0,21 & 0,01 & 0,00 & 0,07 & 0,31 \\
\hline Prunion fruticosae & 0,00 & 0,00 & 0,54 & 0,42 & 0,00 & 0,00 & 0,07 & 0,32 \\
\hline Prunetalia spinosae s.1. & 0,12 & 0,00 & 1,85 & 1,66 & 0,01 & 0,00 & 0,31 & 1,23 \\
\hline Quercetea pubescentis-petraeae s.l. & 1,88 & 0,31 & 16,75 & 13,56 & 0,25 & 0,04 & 23,96 & 17,60 \\
\hline Querco-Fagea s.1. & 38,80 & 33,56 & 58,28 & 49,15 & 53,42 & 61,83 & 91,38 & 81,59 \\
\hline Abieti-Piceea & 0,00 & 0,00 & 0,00 & 0,00 & 0,00 & 0,00 & 0,00 & 0,00 \\
\hline Vaccinio-Piceetea & 0,00 & 0,00 & 0,00 & 0,01 & 0,00 & 0,00 & 0,00 & 0,00 \\
\hline Pino-Quercetalia & 0,00 & 0,00 & 0,00 & 0,00 & 0,00 & 0,00 & 0,00 & 0,00 \\
\hline Pino-Quercion & 0,35 & 1,33 & 0,53 & 0,48 & 0,03 & 0,28 & 0,06 & 0,13 \\
\hline Pino-Quercetalia s.l. & 0,35 & 1,33 & 0,53 & 0,48 & 0,03 & 0,28 & 0,06 & 0,13 \\
\hline Vaccinio-Piceetea s.l. & 0,35 & 1,33 & 0,53 & 0,49 & 0,03 & 0,28 & 0,06 & 0,13 \\
\hline Abieti-Piceea s.l. & 0,35 & 1,33 & 0,53 & 0,49 & 0,03 & 0,28 & 0,06 & 0,13 \\
\hline
\end{tabular}




\section{4. táblázat: Karakterfajok aránya}

\begin{tabular}{|c|c|c|c|c|c|c|c|c|}
\hline 4/2. táblázat & $\begin{array}{r}\text { C } \\
\text { Fr-A Ny }\end{array}$ & $\begin{array}{l}\text { Ssoportré } \\
\text { Fr-A DT }\end{array}$ & $\begin{array}{l}\text { szesedés } \\
\text { V-Fr Ny }\end{array}$ & V-Fr DT & Fr-A Ny & $\begin{array}{r}\text { Csoport } \\
\text { Fr-A DT }\end{array}$ & $\begin{array}{l}\text { ttömeg } \\
\text { V-Fr Ny }\end{array}$ & V-Fr DT \\
\hline Lemno-Potamea & 0,78 & 0,00 & 0,00 & 0,00 & 0,07 & 0,00 & 0,00 & 0,00 \\
\hline Hydrochari-Lemnetea & 0,00 & 0,00 & 0,00 & 0,00 & 0,00 & 0,00 & 0,00 & 0,00 \\
\hline Hydrocharietalia & 0,78 & 0,00 & 0,00 & 0,00 & 0,07 & 0,00 & 0,00 & 0,00 \\
\hline Lemnion minoris & 0,78 & 0,00 & 0,00 & 0,00 & 0,07 & 0,00 & 0,00 & 0,00 \\
\hline Hydrocharietalia s.l. & 1,56 & 0,00 & 0,00 & 0,00 & 0,14 & 0,00 & 0,00 & 0,00 \\
\hline Hydrochari-Lemnetea s.l. & 1,56 & 0,00 & 0,00 & 0,00 & 0,14 & 0,00 & 0,00 & 0,00 \\
\hline Potametea & 0,38 & 0,09 & 0,00 & 0,01 & 0,04 & 0,01 & 0,00 & 0,00 \\
\hline Potametalia & 0,00 & 0,62 & 0,00 & 0,00 & 0,00 & 0,08 & 0,00 & 0,00 \\
\hline Potamion & 0,23 & 0,47 & 0,00 & 0,00 & 0,02 & 0,46 & 0,00 & 0,00 \\
\hline Potametalia s.l. & 0,23 & 1,09 & 0,00 & 0,00 & 0,02 & 0,54 & 0,00 & 0,00 \\
\hline Potametea s.l. & 0,61 & 1,18 & 0,00 & 0,01 & 0,06 & 0,55 & 0,00 & 0,00 \\
\hline Lemno-Potamea s.l. & 2,95 & 1,18 & 0,00 & 0,01 & 0,27 & 0,55 & 0,00 & 0,00 \\
\hline Cypero-Phragmitea & 0,00 & 0,00 & 0,00 & 0,00 & 0,00 & 0,00 & 0,00 & 0,00 \\
\hline Phragmitetea & 11,48 & 9,56 & 2,58 & 4,35 & 8,67 & 4,22 & 0,43 & 1,22 \\
\hline Phragmitetalia & 0,00 & 0,00 & 0,00 & 0,00 & 0,00 & 0,00 & 0,00 & 0,00 \\
\hline Phragmition & 1,25 & 0,57 & 0,00 & 0,00 & 0,59 & 0,81 & 0,00 & 0,00 \\
\hline Phragmitetalia s.1. & 1,25 & 0,57 & 0,00 & 0,00 & 0,59 & 0,81 & 0,00 & 0,00 \\
\hline Nasturtio-Glycerietalia & 0,00 & 0,00 & 0,00 & 0,00 & 0,00 & 0,00 & 0,00 & 0,00 \\
\hline Glycerio-Sparganion & 0,92 & 0,37 & 0,11 & 0,05 & 0,14 & 0,05 & 0,01 & 0,01 \\
\hline Nasturtio-Glycerietalia s.l. & 0,92 & 0,37 & 0,11 & 0,05 & 0,14 & 0,05 & 0,01 & 0,01 \\
\hline Magnocaricetalia & 0,00 & 0,00 & 0,00 & 0,00 & 0,00 & 0,00 & 0,00 & 0,00 \\
\hline Magnocaricion & 3,55 & 6,51 & 2,47 & 2,47 & 6,87 & 4,59 & 0,36 & 1,01 \\
\hline Caricenion rostratae & 0,12 & 1,56 & 0,00 & 0,00 & 0,01 & 0,46 & 0,00 & 0,00 \\
\hline Caricenion gracilis & 1,44 & 0,78 & 0,29 & 0,74 & 5,85 & 0,62 & 0,07 & 0,77 \\
\hline Magnocaricion s.1. & 5,11 & 8,85 & 2,76 & 3,21 & 12,73 & 5,67 & 0,43 & 1,78 \\
\hline Magnocaricetalia s.l. & 5,11 & 8,85 & 2,76 & 3,21 & 12,73 & 5,67 & 0,43 & 1,78 \\
\hline Phragmitetea s.l. & 18,76 & 19,35 & 5,45 & 7,61 & 22,13 & 10,75 & 0,87 & 3,01 \\
\hline Isoëto-Nanojuncetea & 0,00 & 0,00 & 0,00 & 0,00 & 0,00 & 0,00 & 0,00 & 0,00 \\
\hline Nanocyperetalia & 0,00 & 0,00 & 0,00 & 0,00 & 0,00 & 0,00 & 0,00 & 0,00 \\
\hline Nanocyperion flavescentis & 0,63 & 0,16 & 0,00 & 0,04 & 0,10 & 0,02 & 0,00 & 0,00 \\
\hline Isoëto-Nanojuncetea s.l. & 0,63 & 0,16 & 0,00 & 0,04 & 0,10 & 0,02 & 0,00 & 0,00 \\
\hline Cypero-Phragmitea s.1. & 19,39 & 19,51 & 5,45 & 7,65 & 22,23 & 10,77 & 0,87 & 3,01 \\
\hline Oxycocco-Caricea nigrae & 0,00 & 0,00 & 0,00 & 0,00 & 0,00 & 0,00 & 0,00 & 0,00 \\
\hline Scheuchzerio-Caricetea nigrae & 0,00 & 0,00 & 0,00 & 0,00 & 0,00 & 0,00 & 0,00 & 0,00 \\
\hline Scheuchzerio-Caricetalia nigrae & 0,31 & 0,21 & 0,03 & 0,13 & 0,03 & 0,03 & 0,00 & 0,01 \\
\hline Scheuchzerio-Caricetea nigrae s.l. & 0,31 & 0,21 & 0,03 & 0,13 & 0,03 & 0,03 & 0,00 & 0,01 \\
\hline Oxycocco-Caricea nigrae s.l. & 0,31 & 0,21 & 0,03 & 0,13 & 0,03 & 0,03 & 0,00 & 0,01 \\
\hline Molinio-Arrhenatherea & 1,58 & 0,62 & 3,95 & 3,38 & 0,15 & 0,12 & 0,66 & 0,70 \\
\hline Molinio-Juncetea & 3,36 & 5,77 & 2,26 & 4,23 & 5,65 & 2,58 & 0,93 & 3,08 \\
\hline Tofieldietalia & 0,00 & 0,00 & 0,00 & 0,00 & 0,00 & 0,00 & 0,00 & 0,00 \\
\hline Caricion davallianae & 0,00 & 0,35 & 0,04 & 0,00 & 0,00 & 0,07 & 0,00 & 0,00 \\
\hline Tofieldietalia s.l. & 0,00 & 0,35 & 0,04 & 0,00 & 0,00 & 0,07 & 0,00 & 0,00 \\
\hline
\end{tabular}




\section{4. táblázat: Karakterfajok aránya}

\begin{tabular}{|c|c|c|c|c|c|c|c|c|}
\hline \multirow{2}{*}{ 4/3. táblázat } & \multicolumn{4}{|c|}{ Csoportrészesedés } & \multicolumn{4}{|c|}{ Csoporttömeg } \\
\hline & Fr-A Ny & Fr-A DT & V-Fr Ny & V-Fr DT & Fr-A Ny & Fr-A DT & V-Fr Ny & V-Fr DT \\
\hline Molinietalia coeruleae & 1,82 & 2,90 & 2,28 & 1,86 & 0,32 & 0,44 & 0,34 & 0,52 \\
\hline Molinion coeruleae & 0,00 & 0,47 & 0,12 & 0,01 & 0,00 & 0,09 & 0,01 & 0,00 \\
\hline Deschampsion caespitosae & 0,95 & 0,90 & 0,38 & 0,87 & 0,20 & 0,14 & 0,20 & 0,78 \\
\hline Filipendulo-Cirsion oleracei & 0,00 & 1,20 & 1,68 & 0,44 & 0,00 & 0,16 & 0,29 & 0,05 \\
\hline Alopecurion pratensis & 0,09 & 0,00 & 0,00 & 0,02 & 0,01 & 0,00 & 0,00 & 0,00 \\
\hline Molinietalia coeruleae s.1. & 2,86 & 5,47 & 4,46 & 3,20 & 0,53 & 0,83 & 0,84 & 1,35 \\
\hline Molinio-Juncetea s.l. & 6,22 & 11,59 & 6,76 & 7,43 & 6,18 & 3,48 & 1,77 & 4,43 \\
\hline Arrhenatheretea & 0,00 & 0,00 & 0,00 & 0,00 & 0,00 & 0,00 & 0,00 & 0,00 \\
\hline Arrhenatheretalia & 0,00 & 0,00 & 0,38 & 0,18 & 0,00 & 0,00 & 0,05 & 0,02 \\
\hline Arrhenatherion elatioris & 0,00 & 0,00 & 0,41 & 0,24 & 0,00 & 0,00 & 0,05 & 0,05 \\
\hline Cynosurion cristati & 0,00 & 0,00 & 0,00 & 0,03 & 0,00 & 0,00 & 0,00 & 0,00 \\
\hline Arrhenatheretalia s.l. & 0,00 & 0,00 & 0,79 & 0,45 & 0,00 & 0,00 & 0,10 & 0,07 \\
\hline Arrhenatheretea s.l. & 0,00 & 0,00 & 0,79 & 0,45 & 0,00 & 0,00 & 0,10 & 0,07 \\
\hline Nardo-Callunetea & 0,00 & 0,00 & 0,00 & 0,00 & 0,00 & 0,00 & 0,00 & 0,00 \\
\hline Nardetalia & 0,00 & 0,00 & 0,00 & 0,00 & 0,00 & 0,00 & 0,00 & 0,00 \\
\hline Nardo-Agrostion tenuis & 0,00 & 0,00 & 0,40 & 0,06 & 0,00 & 0,00 & 0,05 & 0,01 \\
\hline Nardetalia s.l. & 0,00 & 0,00 & 0,40 & 0,06 & 0,00 & 0,00 & 0,05 & 0,01 \\
\hline Nardo-Callunetea s.1. & 0,00 & 0,00 & 0,40 & 0,06 & 0,00 & 0,00 & 0,05 & 0,01 \\
\hline Molinio-Arrhenatherea s.l. & 7,80 & 12,21 & 11,90 & 11,32 & 6,33 & 3,60 & 2,58 & 5,21 \\
\hline Puccinellio-Salicornea & 0,00 & 0,00 & 0,00 & 0,00 & 0,00 & 0,00 & 0,00 & 0,00 \\
\hline Festuco-Puccinellietea & 0,09 & 0,34 & 0,00 & 0,21 & 0,05 & 0,04 & 0,00 & 0,03 \\
\hline Festuco-Puccinellietalia & 0,58 & 0,55 & 0,15 & 0,50 & 0,13 & 0,35 & 0,02 & 0,06 \\
\hline Beckmannion eruciformis & 0,00 & 0,00 & 0,00 & 0,01 & 0,00 & 0,00 & 0,00 & 0,00 \\
\hline Festuco-Puccinellietalia s.1. & 0,58 & 0,55 & 0,15 & 0,51 & 0,13 & 0,35 & 0,02 & 0,06 \\
\hline Festuco-Puccinellietea s.l. & 0,67 & 0,89 & 0,15 & 0,72 & 0,18 & 0,39 & 0,02 & 0,09 \\
\hline Puccinellio-Salicornea s.1. & 0,67 & 0,89 & 0,15 & 0,72 & 0,18 & 0,39 & 0,02 & 0,09 \\
\hline Festuco-Bromea & 0,00 & 0,00 & 0,24 & 0,13 & 0,00 & 0,00 & 0,03 & 0,01 \\
\hline Festucetea vaginatae & 0,00 & 0,00 & 0,00 & 0,00 & 0,00 & 0,00 & 0,00 & 0,00 \\
\hline Festucetalia vaginatae & 0,00 & 0,00 & 0,00 & 0,00 & 0,00 & 0,00 & 0,00 & 0,00 \\
\hline Festucion vaginatae & 0,00 & 0,00 & 0,05 & 0,04 & 0,00 & 0,00 & 0,01 & 0,00 \\
\hline Festucetalia vaginatae s.1. & 0,00 & 0,00 & 0,05 & 0,04 & 0,00 & 0,00 & 0,01 & 0,00 \\
\hline Festucetea vaginatae s.l. & 0,00 & 0,00 & 0,05 & 0,04 & 0,00 & 0,00 & 0,01 & 0,00 \\
\hline Festuco-Brometea & 0,00 & 0,00 & 0,32 & 0,64 & 0,00 & 0,00 & 0,04 & 0,07 \\
\hline Festucetalia valesiacae & 0,00 & 0,00 & 0,16 & 0,19 & 0,00 & 0,00 & 0,02 & 0,02 \\
\hline Festucion rupicolae & 0,00 & 0,00 & 0,00 & 0,06 & 0,00 & 0,00 & 0,00 & 0,01 \\
\hline Cynodonto-Festucenion & 0,00 & 0,00 & 0,00 & 0,03 & 0,00 & 0,00 & 0,00 & 0,00 \\
\hline Festucion rupicolae s.l. & 0,00 & 0,00 & 0,00 & 0,09 & 0,00 & 0,00 & 0,00 & 0,01 \\
\hline Festucetalia valesiacae s.l. & 0,00 & 0,00 & 0,16 & 0,28 & 0,00 & 0,00 & 0,02 & 0,03 \\
\hline Festuco-Brometea s.l. & 0,00 & 0,00 & 0,48 & 0,92 & 0,00 & 0,00 & 0,06 & 0,10 \\
\hline Festuco-Bromea s.l. & 0,00 & 0,00 & 0,77 & 1,09 & 0,00 & 0,00 & 0,10 & 0,11 \\
\hline Chenopodio-Scleranthea & 0,55 & 0,91 & 0,60 & 0,72 & 0,05 & 0,15 & 0,07 & 0,08 \\
\hline Secalietea & 0,48 & 0,53 & 0,94 & 1,11 & 0,04 & 0,07 & 0,16 & 0,16 \\
\hline Secalietalia & 0,00 & 0,00 & 0,00 & 0,00 & 0,00 & 0,00 & 0,00 & 0,00 \\
\hline Caucalidion platycarpos & 0,00 & 0,00 & 0,00 & 0,05 & 0,00 & 0,00 & 0,00 & 0,01 \\
\hline Secalietalia s.l. & 0,00 & 0,00 & 0,00 & 0,05 & 0,00 & 0,00 & 0,00 & 0,01 \\
\hline Secalietea s.1. & 0,48 & 0,53 & 0,94 & 1,16 & 0,04 & 0,07 & 0,16 & 0,17 \\
\hline
\end{tabular}




\section{4. táblázat: Karakterfajok aránya}

\begin{tabular}{|c|c|c|c|c|c|c|c|c|}
\hline 4/4. táblázat & Fr-A Ny & $\begin{array}{r}\text { Csoportré } \\
\text { Fr-A DT }\end{array}$ & $\begin{array}{l}\text { szesedés } \\
\text { V-Fr Ny }\end{array}$ & V-Fr DT & Fr-A Ny & $\begin{array}{r}\text { Csopor } \\
\text { Fr-A DT }\end{array}$ & $\begin{array}{l}\text { ttömeg } \\
\text { V-Fr Ny }\end{array}$ & V-Fr DT \\
\hline Chenopodietea & 0,12 & 0,00 & 0,20 & 0,47 & 0,01 & 0,00 & 0,02 & 0,05 \\
\hline Onopordetalia & 0,00 & 0,00 & 0,00 & 0,00 & 0,00 & 0,00 & 0,00 & 0,00 \\
\hline Onopordion acanthii & 0,00 & 0,00 & 0,00 & 0,04 & 0,00 & 0,00 & 0,00 & 0,00 \\
\hline Onopordetalia s.l. & 0,00 & 0,00 & 0,00 & 0,04 & 0,00 & 0,00 & 0,00 & 0,00 \\
\hline Chenopodietea s.l. & 0,12 & 0,00 & 0,20 & 0,51 & 0,01 & 0,00 & 0,02 & 0,05 \\
\hline Artemisietea & 0,00 & 0,00 & 0,00 & 0,00 & 0,00 & 0,00 & 0,00 & 0,00 \\
\hline Artemisietalia & 0,00 & 0,00 & 0,00 & 0,00 & 0,00 & 0,00 & 0,00 & 0,00 \\
\hline Arction lappae & 0,49 & 0,47 & 0,78 & 0,58 & 0,09 & 0,72 & 0,09 & 0,07 \\
\hline Artemisietalia s.l. & 0,49 & 0,47 & 0,78 & 0,58 & 0,09 & 0,72 & 0,09 & 0,07 \\
\hline Artemisietea s.1. & 0,49 & 0,47 & 0,78 & 0,58 & 0,09 & 0,72 & 0,09 & 0,07 \\
\hline Galio-Urticetea & 0,00 & 0,00 & 0,00 & 0,00 & 0,00 & 0,00 & 0,00 & 0,00 \\
\hline Calystegietalia sepium & 0,00 & 0,00 & 0,00 & 0,00 & 0,00 & 0,00 & 0,00 & 0,00 \\
\hline Galio-Alliarion & 0,38 & 0,83 & 2,33 & 1,57 & 0,08 & 0,77 & 0,38 & 0,19 \\
\hline Calystegion sepium & 4,57 & 3,48 & 1,54 & 2,44 & 2,97 & 1,25 & 0,47 & 0,34 \\
\hline Calystegietalia sepium s.l. & 4,95 & 4,31 & 3,87 & 4,01 & 3,05 & 2,02 & 0,85 & 0,53 \\
\hline Galio-Urticetea s.l. & 4,95 & 4,31 & 3,87 & 4,01 & 3,05 & 2,02 & 0,85 & 0,53 \\
\hline Bidentetea & 0,00 & 0,00 & 0,00 & 0,00 & 0,00 & 0,00 & 0,00 & 0,00 \\
\hline Bidentetalia & 2,92 & 2,34 & 0,84 & 1,18 & 0,86 & 0,39 & 0,15 & 0,14 \\
\hline Bidention tripartiti & 0,64 & 0,68 & 0,03 & 0,18 & 0,17 & 0,12 & 0,00 & 0,02 \\
\hline Chenopodion rubri & 0,31 & 0,00 & 0,00 & 0,00 & 0,03 & 0,00 & 0,00 & 0,00 \\
\hline Bidentetalia s.l. & 3,87 & 3,02 & 0,87 & 1,36 & 1,06 & 0,51 & 0,15 & 0,16 \\
\hline Bidentetea s.l. & 3,87 & 3,02 & 0,87 & 1,36 & 1,06 & 0,51 & 0,15 & 0,16 \\
\hline Plantaginetea & 0,00 & 0,00 & 0,00 & 0,00 & 0,00 & 0,00 & 0,00 & 0,00 \\
\hline Plantaginetalia majoris & 0,67 & 0,48 & 0,27 & 0,44 & 0,14 & 0,15 & 0,03 & 0,05 \\
\hline Agropyro-Rumicion crispi & 0,00 & 0,00 & 0,00 & 0,03 & 0,00 & 0,00 & 0,00 & 0,00 \\
\hline Plantaginetalia majoris s.l. & 0,67 & 0,48 & 0,27 & 0,47 & 0,14 & 0,15 & 0,03 & 0,05 \\
\hline Plantaginetea s.l. & 0,67 & 0,48 & 0,27 & 0,47 & 0,14 & 0,15 & 0,03 & 0,05 \\
\hline Epilobietea angustifolii & 0,00 & 0,00 & 0,00 & 0,00 & 0,00 & 0,00 & 0,00 & 0,00 \\
\hline Epilobietalia & 1,69 & 1,71 & 4,54 & 3,48 & 0,20 & 0,88 & 0,79 & 0,87 \\
\hline Epilobion angustifolii & 0,00 & 0,00 & 0,05 & 0,00 & 0,00 & 0,00 & 0,01 & 0,00 \\
\hline Epilobietalia s.1. & 1,69 & 1,71 & 4,59 & 3,48 & 0,20 & 0,88 & 0,80 & 0,87 \\
\hline Epilobietea angustifolii s.l. & 1,69 & 1,71 & 4,59 & 3,48 & 0,20 & 0,88 & 0,80 & 0,87 \\
\hline Urtico-Sambucetea & 0,00 & 0,00 & 0,00 & 0,00 & 0,00 & 0,00 & 0,00 & 0,00 \\
\hline Sambucetalia & 0,00 & 0,00 & 0,00 & 0,00 & 0,00 & 0,00 & 0,00 & 0,00 \\
\hline Sambuco-Salicion capreae & 0,12 & 0,43 & 0,26 & 0,35 & 0,01 & 0,06 & 0,03 & 0,36 \\
\hline Sambucetalia s.l. & 0,12 & 0,43 & 0,26 & 0,35 & 0,01 & 0,06 & 0,03 & 0,36 \\
\hline Urtico-Sambucetea s.l. & 0,12 & 0,43 & 0,26 & 0,35 & 0,01 & 0,06 & 0,03 & 0,36 \\
\hline Chenopodio-Scleranthea s.1. & 12,94 & 11,86 & 12,38 & 12,64 & 4,65 & 4,56 & 2,20 & 2,34 \\
\hline Indifferens & 3,46 & 4,36 & 3,84 & 4,88 & 0,44 & 3,35 & 0,82 & 3,65 \\
\hline Adventiva & 0,47 & 1,25 & 1,95 & 3,82 & 0,04 & 8,80 & 1,10 & 0,80 \\
\hline
\end{tabular}




\section{Irodalom}

Becking, R. W. 1957: The Zürich-Montpellier School of phytosociology. - Botanical Review 23: 411-488.

Borhidi A. 1993: A magyar flóra szociális magatartás típusai, természetességi és relatív ökológiai értékszámai. - Janus Pannonius Tudományegyetem, Pécs, 95 pp.

BorHIDi A. 1995: Social behaviour types, the naturalness and relative ecological indicator values of the higher plants in the hungarian flora. - Acta Botanica Academiae Scientiarum Hungaricae 39: 97-181.

Borhidi A. \& KeVEY B. 1996: An annotated checklist of the Hungarian plant communities II. - In: BorHIDI A. red.). Critical revision of the Hungarian plant comuunities. - Janus Pannonius University, Pécs, pp. 95-138.

Borhidi A., Kevey B. \& Lendvai G. 2012: Plant communities of Hungary. Akadémiai Kiadó, Budapest, 544 pp.

Braun-Blanquet, J. 1964: Pflanzensoziologie (ed. 3.). Springer Verlag, Wien-New York, 865 pp.

Horváth F., Dobolyi Z. K., MorschHauser T., LöKös L., KARAS L. \& Szerdahelyi T. 1995: Flóra adatbázis 1.2. - Vácrátót, $267 \mathrm{pp}$.

JAKUCS P. 1967: Gedanken zur höheren Systematik der europäischen Laubwälder. - Contribuţii Botanice Cluj 1967: 159-166.

JÁrAI-KomlóDi M. 1958: Die Pflanzengesellschaften in dem Turjángebiet von Ócsa-Dabas. - Acta Botanica Academiae Scientiarum Hungaricae 4: 63-92.

KEveY B. 2008: Magyarország erdőtársulásai (Forest associations of Hungary). Die Wälder von Ungarn. Tilia 14: 1-488. + CD-adatbázis (230 táblázat + 244 ábra).

Kevey B. 2020: A Duna-Tisza köze kiszáradó kőrislápjai (Veratro albi-Fraxonetum angustifoliae). - Botanikai Közlemények 107(2): 221-242 + E1-8. táblázat. DOI: https://doi.org/10.17716/ BotKozlem.2020.107.2.221.

Kevey B. \& Papp L. 2020: Töredékes égerligetek a Nyírségben (Paridi quadrifoliae-Alnetum glutinosae Kevey in Borhidi et Kevey 1996). - Natura Somogyiensis 34: 127-152. DOI: https://doi.org/10.24394/ NatSom.2020.34.127.

Kevey B., Lendvai G. \& Papp L. 2019: Drained ash swamp (Veratro albi-Fraxinetum angustifoliae), a new association in the Nyírség, NE Hungary. - Acta Botanica Hungarica 61 (1-2): 55-99. DOI: https://doi. org/10.1556/034.61.2019.1-2.7.

KeVEy B. \& HiRmann A. 2002: „NS” számítógépes cönológiai programcsomag. - In: Aktuális flóra- és vegetációkutatások a Kárpát-medencében V. Pécs, 2002. március 8-10. (Összefoglalók), pp.: 74.

KIRÁLY G. (szerk.) 2009: Új magyar füvészkönyv. Magyarország hajtásos növényei. Határozókulcsok. Aggteleki Nemzeti Park Igazgatóság, Jósvafö, 616 pp.

Malcuit, G. 1929: Les associations végétales de la Vallée de la Lanterne. - Archives de Botanique, Bulletin Mensuel, Caën 2: 142-154.

Mucina, L., Grabherr, G. \& WallnöFer, S. 1993: Die Pflanzengesellschaften Österreichs III. Wälder und Gebüsche. - Gustav Fischer, Jena - Stuttgart - New York, 353 pp.

OBerdorfer, E. 1992: Süddeutsche Pflanzengesellschaften IV. A. Textband. - Gustav Fischer Verlag, Jena Stuttgart - New York, $282 \mathrm{pp}$.

Podani J. 2001: SYN-TAX 2000 Computer Programs for Data Analysis in Ecologi and Systematics. Scientia, Budapest, 53 pp.

Soó R. 1964, 1966, 1968, 1970, 1973, 1980: A magyar flóra és vegetáció rendszertani-növényföldrajzi kézikönyve I-VI. - Akadémiai Kiadó, Budapest.

TüxEN, R. 1937: Die Pflanzengesellschaften Nordwestdeutschlands. - Mittelilungen der Floristisch.Soziologischen Arbeitsgemeinschaft in Niedersachsen, Hannover 3: 1-170.

Westhoff, V., Dijk, J.W. \& Passchier H. 1946: Overzicht der plantengemeenschappen in Nederland. Tweede druk, G.W. Breughel, Amsterdam, 118 pp. 